22

\title{
積雪寒冷地水田におけるタイヌビエの種子生産量と土中種子数 の増減予測モデル
}

${ }^{\circ}$ 渡邊寬明・内野 彰・橘雅明（東北農業研究センター）

演者らはタイヌビエの要防除水準を策定するために、土中種子数の増減（変化）を 予測するモデルを作成した。本モデルは、ある年 $\mathrm{t}$ の土中種子数 $\mathrm{SP}(\mathrm{t})$ とその年間生 存率 $\mathrm{SV}_{1}$ 、および種子生産量 $\mathrm{P}$ とその越冬生存率 $\mathrm{SV}_{2}$ から、翌年 $\mathrm{t}+1$ の土中種子数 $\mathrm{SP}(\mathrm{t}+1)$ を推定するものである（式 1$) 。 \mathrm{SV}_{1}$ と $\mathrm{SV}_{2}$ は、前報で得られた值 $(0.4,0.73)$ を用いるが、 $\mathrm{P}$ を推定するためのパラメータを得るために直場試験を行った。

（式 1） $\mathrm{SP}(\mathrm{t}+1)=\mathrm{SP}(\mathrm{t}) \times \mathrm{SV}_{1}+\mathrm{P} \times \mathrm{SV}_{2}$

<材料及び方法 $>$

前報で土中種子数の推移を調査した東北農業研究センターの $50 \mathrm{~m}^{2}$ 水田 12 筆におい て、2002 年の水稲作では各水田の $25 \mathrm{~m}^{2}$ は前報で示した完全除草区、薬剤除草区、機 械除草区、無除草区として管理し、残りの $25 \mathrm{~m}^{2}$ は無除草とした。代かき時に各水田 の無除草部分のタイヌビエ生存種子数を調査し (土壌 $500 \mathrm{ml} \times 5$ 力所)、水稲収穫前に 地上部乾物重を調査した $\left(1 \mathrm{~m}^{2} \times 3\right.$ 力所)。各水田の除草部分の種子生産量は、穂に袋 をかけた個体の乾物重と生産種子数との関係式を用い、収穫期の残草量から算出した。 <結果及び考察 $>$

種子生産量と残草量（収穫期地上部乾物重）との間には高い正の相関が認められた ことから (第 1 図)、単回帰式 (式 2) を除草区残草量 Ge から種子生産量 P を推定する 式とした。Ge は無処理区残草量 $\mathrm{G}$ と除草効果 $\mathrm{E}$ により決まる (式 3)。

（式 2） $\mathrm{P}=84.821 \times \mathrm{Ge}-42.728 \quad$ (式 3) $\mathrm{Ge}=\mathrm{G} \times(1-\mathrm{E})$

$\mathrm{G}$ は $\mathrm{SP}(\mathrm{t})$ が 1000 粒 $/ \mathrm{m}^{2}$ 以下の土中種子数であれば $\mathrm{SP}(\mathrm{t})$ の増加にともない増大した が、1000 粒/ $\mathrm{m}^{2}$ を越えるとほぼ一定となったことから (第 2 図)、対数ロジスティック 曲線を当てはめることにより、SP(t)から G の推定が可能と考えられた (式 4)。

（式 4） $\mathrm{G}=277.59 /(1+\exp (-1.6288 \times(\ln (\mathrm{SP}(\mathrm{t}))-\ln (351.32))))$

したがって、式 2〜 より、種子生産量 $\mathrm{P}$ は $\mathrm{SP}(\mathrm{t})$ と除草効果 $\mathrm{E}$ により推定可能とな り、翌年の土中種子数 $\mathrm{SP}(\mathrm{t}+1)$ も $\mathrm{SP}(\mathrm{t})$ と E から予測できると考えられた (第 3 図)。

$2000 \sim 2002$ 年の圃場試験で得られた各処理区の除草効果（完全除草 1 , 薬剤除草 0.98 , 機械除草 0.46 , 無除草 0) を用いて、初期土中種子数からその後 4 年間の種子数 推移を推定した (第 4 図)。また、前年度の土中種子数を用いた一年毎の翌年種子数の 推定も行った (第 5 図)。いずれの場合も、除草効果が高い場合に本モデルによる推定 值は実測值とよく一致した。任意の土中種子数と除草効果を用いたシミュレーション 結果によれば、土中種子数 1000 粒 $/ \mathrm{m}^{2}$ から種子数を減らすには除草効果 0.97 以上、100 粒 $/ \mathrm{m}^{2}$ から種子数を減らすには除草効果 0.99 以上が求められると予測された (第 6 図)。

以上のように、タイヌビエの土中種子数を低い密度で維持するためには、極めて高 い除草効果が必要とされることが、本モデルから導き出された。

A simulation model for seed population of Echinochloa oryzicola Vasing. based on its seed production in rice fields in the cool temperate snow area.

Watanabe, H., Uchino, A. and Tachibana, M. 


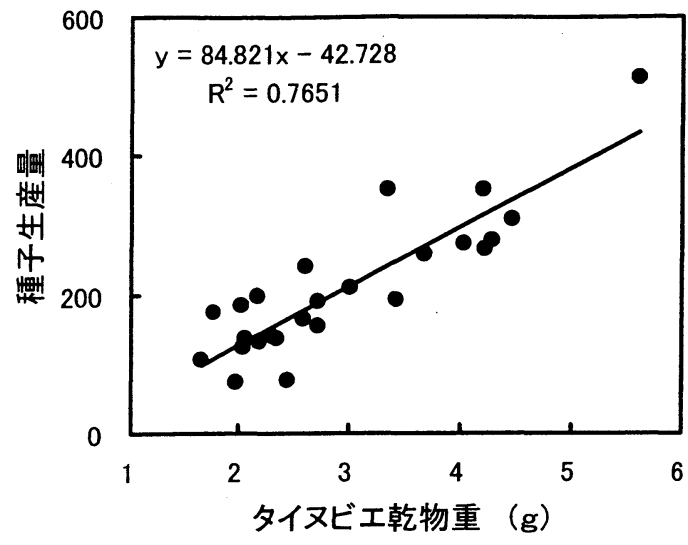

第1図 タイヌビエ残存個体の乾物重と 種子生産量との関係

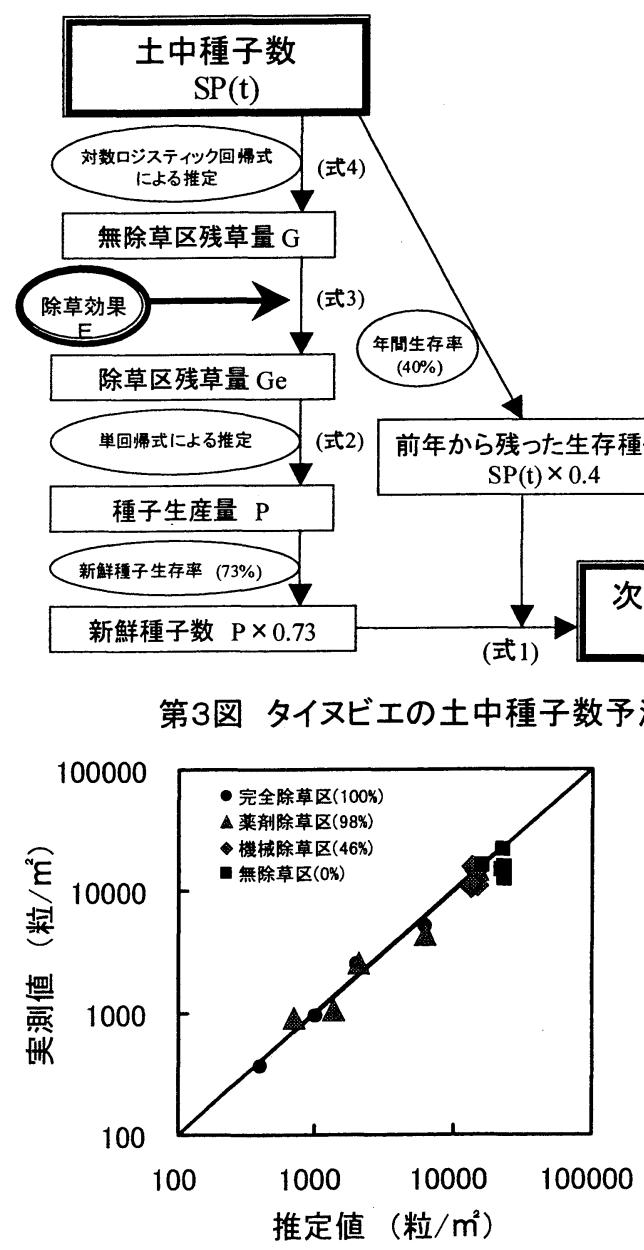

第5図 前年度土中種子数と除草効果から推定し た次年度土中種子数と実測値との関係

(図中括弧内は推定に用いた除草効果を示す)

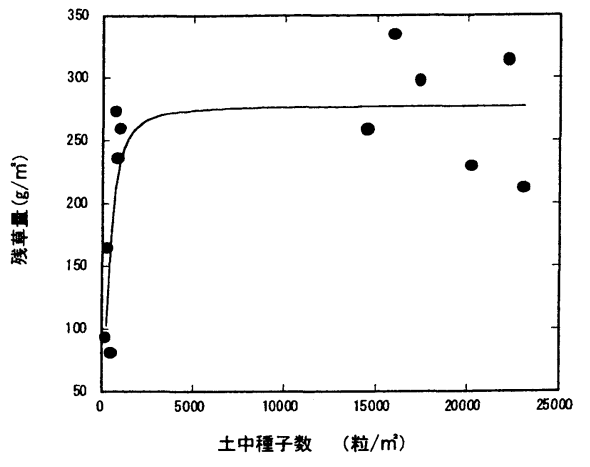

第2圈水程作付壮剪の土中程子

回㷌式 $y=277.59 /(1+\exp (-1.6288 *(\ln (x)-\ln (351.32))))$ $\mathrm{R}^{2}=0.60$

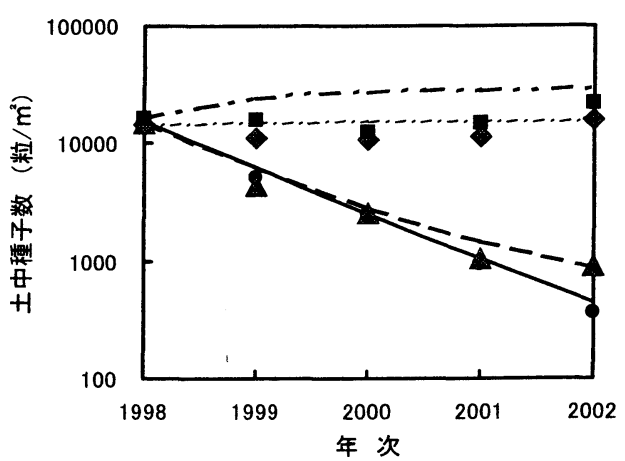

第4図 1998年水稲作付け前の土中種子数を 初期値とした場合の種子数推移の推定

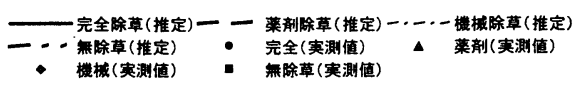

次年度土中種子数

$\mathrm{SP}(\mathrm{t}+1)$ 